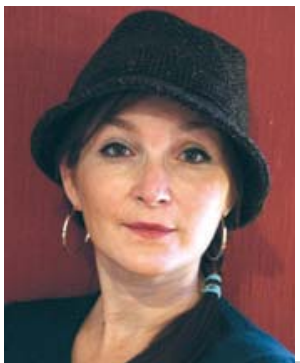

Tale Næss

Forfatter og dramatiker

Foto: Trond Peter Stamsø Munch

\title{
Mur de la peste
}

\section{Til alle tider er det blitt bygd murer i verden. Murer som skal holde ute invasjonshærer, murer som skal holde tilbake flyktningstrømmer, murer som skal skille de syke fra de friske.}

Da den store pesten rammet Marseille i 1720, ble det reist en to meter høy mur på tvers av plateau de Vaucluse. Pesten kom over havet fra Libanon. Om bord var en tyrkisk passasjer. Mannen døde på overfarten. Da skipet ankom Marseille, var flere av mannskapet syke. Fartøyet ble øyeblikkelig satt i karantene, men myndighetene ble snart satt under press av innflytelsesrike kjøpmenn som hadde varer om bord og ville ha karantenen løftet.

I 1720 var det fransk monopol på handelen med Levanten. Man var i ferd med å ekspandere til markeder i den nye verden. Det hastet med å få losset varene. Få dager etter at karantenen var løftet, brøt sykdommen ut. Snart lå det hauger av lik i gatene. Byen var isolert. Straffen for å ha noen som helst kontakt med den var døden.

Det er sånt man drømmer. At man sitter i senga og ser nedover seg selv og oppdager at kroppen er dekket av store byller. Det er slike drømmer der alle tennene øøsner og faller ut. Drømmer om mørke rom der du sitter med trekk så deformerte at du ikke er til å kjenne igjen.

Vi lever tett på hverandre. Samfunnet gir både plikter og rettigheter. Papirene vi innehar, gir oss mulighet til å være borgere på lik linje med andre borgere, men vi vet et sted dypt i oss hvor lett det er å falle utenfor. Hvor lett det er å havne på feil side av muren. På det stedet der demokratiet opphører. Der vi ikke lenger er en del av samfunnet - beskyttet, likeverdig, fri til å dra hvor vi vil.

Norges lover gir alle innbyggere rett til helsehjelp, til pleie og omsorg. Til forebyggende tiltak og behandling. Men smittevernloven av 5. august 1994 understreker også at om nødvendig kan tvangstiltak innføres: tvungen undersøkelse, tvungen isolering, tvungen innleggelse $i$ isolat. Den henviser til karantenetiltak for ferdsel inn og ut av landet. Møteforbud, stenging av virksomhet, begrensning av kommunikasjon og isolering av geografisk begrensede områder.

I Marseille bar alle pesten med seg. Ingen var trygge. Heller ikke kjøpmennene som hadde insistert på å få løftet karantenen. Varene deres beholdt sin markedsverdi, men sykdommen de hadde brakt med seg konsumerte nå også kroppene til tjenerskapet som skulle tjene dem, helsepersonalet som skulle pleie dem, prestene som skulle sørge for å få dem i jorden.

\section{Så sårbare er vi.}

Mens jeg skriver dette, herjer stormen Hilde over landet. Jeg sitter på toppen av Tromsøya og ser utover byen. Det snør. Under meg ligger det gamle sykehuset. Jeg sitter og forestiller meg at en båt seiler inn Tromsøsundet. Om bord er en bakterie eller et virus vi ikke er resistente mot. Jeg forestiller meg at jeg våkner og at kroppen min er dekket av byller. Jeg forestiller meg at jeg ikke lenger får lov til å forlate huset, gå på jobben, treffe venner, slektninger. At det nye sykehuset sør på øya fylles opp av syke og at de etter hvert samler oss der, i det gamle sykehuset. Der fyller vi sovesaler, korridorer, rom som var ment for andre ting.

Og etter hvert som tida går og vi ikke ble friskere, så frakter de oss ut av byen, opp til et gammelt, nedlagt hotell - og der låser de dørene og trapper ned behandlingen fordi den er kostbar og allikevel ikke nytter. Om noen måneder vil en av pasientene forsøke å rømme, og politiet vil sette vakter ved døra. En annen vil klare å komme seg ut bakveien, ned til bygda gjennom skogen, og lokalbefolkningen vil skrive avisinnlegg om at de ønsker oss bort. At det ikke lenger er trygt for barna deres, for dem selv, med oss der.

Og noen vil forsvare oss og si at de er da mennesker, de også, og myndighetene vil gjøre et vedtak om at det skal reises et sikkerhetsgjerde rundt hotellet, og måneder blir til år og der sitter vi. I stillheten. I en november til forveksling lik denne. Som asylsøkerne i et av den nye regjeringens framtidige mottak. Til så mye tid er gått at samfunnet har vent seg til det. Vi der oppe. De der nede. Nordlyset flammer over trærne, over dampen fra munnene våre der vi står, i luftegården bak sikkerhetsgjerdet og venter på at noen skal rive det.

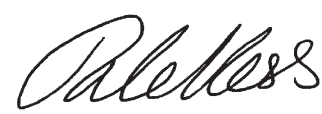

